\title{
Impaired Metabolic Function and Signaling Defects in Phagocytic Cells in Glycogen Storage Disease Type 1b
}

L. Kilpatrick, B.-Z. Garty, K. F. Lundquist, K. Hunter, C. A. Stanley, L. Baker, S. D. Douglas, and H. M. Korchak

Department of Pediatrics, University of Pennsylvania Medical School, Children's Hospital of Philadelphia,

Philadelphia, Pennsylvania 19104

\begin{abstract}
Patients with glycogen storage disease (GSD) type $1 \mathrm{~b}(1 \mathrm{~b})$, in contrast to patients with GSD type 1a (1a), are susceptible to recurrent bacterial infections suggesting an impairment in their immune system. In this study, phagocytic cell (neutrophil and monocyte) respiratory burst activity, as measured by superoxide anion generation, oxygen consumption, and hexose monophosphate shunt activity, was markedly reduced in both neutrophils and monocytes from GSD $1 \mathrm{~b}$ patients as compared with either GSD 1a patients or healthy adult control cells. Degranulation, unlike respiratory burst activity, was not significantly different in neutrophils from GSD $1 \mathrm{~b}$ patients as compared with controls. Both neutrophils and monocytes from GSD $1 \mathrm{~b}$ patients showed decreased ability to elevate cytosolic calcium in response to the chemotactic peptide f-Met-LeuPhe. In addition, calcium mobilization in response to ionomycin was also attenuated suggesting decreased calcium stores. Thus, reduced phagocytic cell function in GSD $1 \mathrm{~b}$ is associated with diminished calcium mobilization and defective calcium stores. Defective calcium signaling is associated with a selective defect in respiratory burst activity but not degranulation. (J. Clin. Invest. 1990. 86:196-202.) Key words: glycogen storage disease $\bullet$ respiratory burst $\bullet$ calcium mobilization
\end{abstract}

\section{Introduction}

In both glycogen storage disease (GSD) $)^{1}$ type $1 \mathrm{a}(1 \mathrm{a} ; 1,2)$ and type $1 \mathrm{~b}(1 \mathrm{~b} ; 3-5)$ inherited hepatic defects prevent the conversion of glucose-6-phosphate to glucose resulting in hypoglycemia during fasting. The clinical features of GSD $1 \mathrm{~b}$ are indistinguishable from GSD 1a with the exception that patients with GSD $1 \mathrm{~b}$ are often neutropenic and are prone to recurrent infections whereas patients with GSD 1a are not (6-11).

Critical to host defense against infections are circulating phagocyte cells (i.e., neutrophils and monocytes). There is in-

A preliminary report of these studies was presented at the Society of Pediatric Research Meeting, Washington, DC, 1988 and at the American Society for Clinical Investigation Meeting, Washington, DC, 1988.

Address correspondence to Dr. Kilpatrick, Division of Infectious Diseases and Immunology, Children's Hospital of Philadelphia, 34 St. and Civic Center Blvd., Philadelphia, PA 19104.

Received for publication 9 February 1989 and in revised form 22 January 1990.

1. Abbreviations used in this paper: GSD, glycogen storage disease; HMPS, hexose monophosphate shunt; $1 \mathrm{a}$ and $1 \mathrm{~b}$, types $1 \mathrm{a}$ and $1 \mathrm{~b}$ of GSD.

J. Clin. Invest.

(c) The American Society for Clinical Investigation, Inc 0021-9738/90/07/0196/07 \$2.00

Volume 86, July 1990, 196-202 creasing evidence of functional defect(s) in GSD $1 \mathrm{~b}$ patients' phagocytic cells which limits their ability to destroy invading microorganisms. Defects in neutrophil chemotaxis and bactericidal activity have been described $(8,12-15)$. An important mechanism in phagocyte bactericidal activity is a process termed respiratory burst activity. The activation of phagocytes by a variety of stimuli can trigger the respiratory burst by activating the assembly of an active NADPH oxidase which catalyzes the reduction of oxygen to superoxide anion. NADPH serves as a source of reducing equivalents and is oxidized to NADP. Elevated levels of NADP allows a more rapid conversion of glucose-6-phosphate to $\mathrm{CO}_{2}$ via the hexose monophosphate shunt (HMPS). Respiratory burst activity is greatly reduced in GSD $1 \mathrm{~b}$ neutrophils $(9,10,12,16)$; however, the specific defect in neutrophils is unknown. Whether this defect is similar to that observed in the liver or is unique to neutrophils has not been determined. Glucose-6-phosphatase activity is dependent on the coupling of three integral microsomal membrane components: $(a)$ a glucose-6-phosphate specific translocase, $(b)$ the enzyme glucose-6-phosphatase, a nonspecific phosphohydrolase, and $(c)$ a phosphate translocase which mediates the efflux of inorganic phosphate (17-19). It is not readily apparent how a defect in the glucose-6-phosphate translocase (GSD lb) can produce alterations in phagocytic cell function, while the absence of the enzyme glucose-6-phosphatase (GSD 1a) does not, since the absence of either component will impair hydrolysis of glucose-6-phosphate.

The purpose of this study was to characterize respiratory burst activity in neutrophils and monocytes from three patients with GSD $1 \mathrm{~b}$ in response to different stimuli. Respiratory burst activity was measured by three independent parameters (superoxide anion generation, oxygen consumption, and HMPS activity [glucose conversion to $\mathrm{CO}_{2}$ ]). All three parameters were decreased in neutrophils from GSD $1 \mathrm{~b}$ patients but not neutrophils from GSD la patients as compared with controls. Respiratory burst activity was also reduced in monocytes from GSD $\mathrm{lb}$ patients as compared with either controls or GSD 1a patients, indicating that the abnormality in respiratory burst activity is not unique to these patients' neutrophils. In contrast to decreased respiratory burst activity, degranulation in neutrophils from GSD $1 \mathrm{~b}$ patients was not significantly different from control neutrophils indicating that not all phagocyte cellular functions are altered in this disease. Finally, to investigate whether the signaling mechanisms involved in regulating respiratory burst activity were altered in this disease, calcium mobilization in response to the stimulus f-Met-LeuPhe was assessed in phagocytic cells from GSD $1 \mathrm{~b}$ patients and compared with those obtained from GSDla patients and controls. Calcium mobilization was decreased in both neutrophils and monocytes from GSD $1 \mathrm{~b}$ patients. In addition, calcium mobilization by a calcium ionophore was reduced in GSD $1 \mathrm{~b}$, indicating reduced intracellular stores. Thus, a selective defect 
in respiratory burst activity is associated with a signaling defect in these patients' phagocytic cells.

\section{Methods}

Blood samples. The study population consisted of three unrelated GSD $1 \mathrm{~b}$ patients: two females aged 3 and $8 \mathrm{yr}$ and one male aged $22 \mathrm{yr}$; two of these patients have been previously reported (14). Also enrolled in the study were seven unrelated GSD la patients.between the ages of 5 and $28 \mathrm{yr}$ of which four were males and three were females. Written permission was obtained from parents of GSD $1 \mathrm{a}$ and GSD $1 \mathrm{~b}$ patients for all blood samples in accordance with policies of the Institutional Review Board at the Children's Hospital of Philadelphia. Control blood samples were obtained from healthy adults routinely used as donors in our laboratory.

Neutrophil separation (20). Neutrophils were isolated from heparinized blood $(10 \mathrm{U} / \mathrm{ml})$ by Ficoll-Hypaque centrifugation and dextran sedimentation, followed by hypotonic lysis to remove residual erythrocytes. Cells were washed twice and resuspended in phosphate buffered saline containing $5 \mathrm{mM}$ glucose.

Monocyte separation (21). Monocytes were separated from neutrophils by the Ficoll-Hypaque centrifugation method described above and resuspended in Dulbecco's modified Eagle's medium (DME) with $4 \mathrm{mM}$ glutamine and penicillin/streptomycin. The cell suspension was plated onto gelatin coated flasks and incubated at $37^{\circ} \mathrm{C}$ for $45 \mathrm{~min}$ in $5 \% \mathrm{CO}_{2}-95 \%$ air. Nonadherent cells were removed by washing the flasks several times with DME. Adherent monocytes were detached by the addition of $5 \mathrm{mM}$ EDTA in DME with $20 \%$ fetal bovine serum, washed, and resuspended in DME with $20 \%$ fetal bovine serum. These cell populations were $92-96 \%$ monocytes, based on latex ingestion and nonspecific esterase staining.

Lymphocyte separation. Lymphocytes were isolated by the FicollHypaque method described above. The nonadherent cells cited in the monocyte preparation contain lymphocytes and platelets. These cell suspensions were removed from the flasks after the 45-min incubation and washed several times in PBS to remove contaminating platelets.

Oxygen consumption. Aliquots of cell suspensions (1-2 $\times 10^{6}$ cells $/ \mathrm{ml}$ ) were transferred into a polarographic chamber and oxygen uptake was measured using a Clark-type oxygen electrode. Basal oxygen consumption was measured for $5 \mathrm{~min}$ before the addition of $0.5 \mu \mathrm{g}$ of phorbol myristate acetate (PMA)/ml. Oxygen consumption after PMA stimulation was expressed as nanomoles of $0_{2}$ per minute per $10^{6}$ cells.

HMPS activity. Flux through the HMPS was determined according to the method of Newburger et al. (22) by monitoring the rate of production of ${ }^{14} \mathrm{CO}_{2}$ from $\left[1-{ }^{14} \mathrm{C}\right]$ glucose and $\left[6-{ }^{14} \mathrm{C}\right]$ glucose. Cell suspensions $\left(1.0 \times 10^{6}\right.$ cells $\left./ \mathrm{ml}\right)$ were incubated for $30 \mathrm{~min}$ at $37^{\circ} \mathrm{C}$ in 25-ml erlenmeyer flasks in the absence (resting) or presence (stimulated) of PMA $(0.5 \mu \mathrm{g} / \mathrm{ml})$. The reaction was initiated by the addition of $2 \mathrm{mM}$ glucose containing $0.25 \mathrm{uCi} / \mathrm{ml}$ of $\left[1-{ }^{14} \mathrm{C}\right]$ glucose or $\left[6-{ }^{14} \mathrm{C}\right]$ glucose. HMPS activity was calculated as the difference between stimulated and resting $\mathrm{CO}_{2}$ release from $\left[1-{ }^{14} \mathrm{C}\right]$ glucose minus that from $\left[6-{ }^{14} \mathrm{C}\right]$ glucose.

Superoxide anion production. Superoxide anion generation by neutrophils and monocytes was determined by following the reduction of cytochrome $c$ by the continuous recording method as previously described (23).

Neutrophil degranulation. To monitor the release of both azurophil and specific granule contents, neutrophils were pretreated with cytochalasin B $(5 \mu \mathrm{g} / \mathrm{ml})$. $\beta$-Glucuronidase, an azurophil granule marker, was determined by incubation with phenolphthalein glucuronidate as substrate (24). Lysozyme, a marker for specific and azurophil granules, was determined as the rate of lysis of Micrococcus lysodeikticus, measured by the decrease in absorbance at $450 \mathrm{~nm}$ (25). Total enzyme activities were determined simultaneously in duplicate reaction mixtures containing the detergent Triton X-100 (0.2\% final concentration).
Fura-2 fluorescence spectroscopy. Cytosolic free calcium concentrations were determined in fura-2-loaded neutrophils and monocytes according to the method of Korchak et al. (26). Cells were incubated in $10 \mu \mathrm{M}$ fura-2 acetoxymethyl (AM) in Hepes buffer at $37^{\circ} \mathrm{C}$ for $5 \mathrm{~min}$. This suspension was then diluted 10 -fold with Hepes buffer at $37^{\circ} \mathrm{C}$ and incubated for a further $20 \mathrm{~min}$. Suspensions were centrifuged $(800$ $\mathrm{rpm}, 10 \mathrm{~min}$ ) and cells resuspended in buffer. This loading protocol optimizes fura-2AM uptake and its conversion to the free acid fura-2 and results in a cell-associated concentration of $0.5 \mu \mathrm{M}$ fura-2. Immediately before use, aliquots of $0.5 \mathrm{ml}$ were microfuged and the cells were resuspended in fresh buffer at a cell concentration of $2.5 \times 10^{6}$ cells $/ \mathrm{ml}$. Fluorescence changes were monitored in a stirred suspension of preloaded cells, at the dual excitation wavelengths of 340 and 380 $\mathrm{nm}$ and emission $505 \mathrm{~nm}$, and cytosolic calcium concentrations were calculated by the ratio method of Grynkiewicz et al. (27).

Statistics. Values were expressed as the mean \pm standard deviation of the mean (SD). Student's $t$ test was used for statistical analysis; a $P$ value of $<0.01$ was accepted as significant.

\section{Results}

\section{Respiratory burst activity}

Measurements of oxygen consumption, HMPS activity, and superoxide generation were made in order to determine whether phagocytic respiratory burst activity was altered in neutrophils and monocytes from GSD $1 \mathrm{~b}$ patients as compared with either GSD la patients or controls.

Oxygen consumption. Table I shows the rate of oxygen consumption after stimulation with PMA in neutrophils and monocytes from patients with GSD $1 \mathrm{~b}$ and GSD $1 \mathrm{a}$ and controls. The rate of stimulated oxygen consumption in neutrophils from GSD $1 \mathrm{~b}$ patients was $1.4 \mathrm{nmol} \mathrm{O}_{2} / \mathrm{min}$ per $10^{6}$ cells; whereas oxygen consumption was 4.9 and $5.6 \mathrm{nmol} \mathrm{O}_{2} / \mathrm{min}$ per $10^{6}$ cells from controls and GSD la patients, respectively. Rates of oxygen consumption were also lower in neutrophils from GSD $1 \mathrm{~b}$ patients than in neutrophils from controls when latex beads were used as stimuli (data not shown). As shown in Table I, monocytes from GSD ib patients also showed a decreased response $\left(1.1 \mathrm{nmol} \mathrm{O}_{2} / \mathrm{min}\right.$ per $10^{6}$ cells $)$ to PMA from that of monocytes from GSD la patients $\left(2.2 \mathrm{nmol} \mathrm{O}_{2} / \mathrm{min}\right.$ per $10^{6}$ cells) and controls $\left(2.5 \mathrm{nmol} \mathrm{O}_{2} / \mathrm{min}\right.$ per $10^{6}$ cells $)$.

HMPS activity. As shown in Table II, after stimulation with PMA, HMPS activity was increased 9.8-fold in neutrophils from control and 7.4-fold in neutrophils from GSD la patients. In contrast, the addition of PMA to neutrophils from

Table I. Oxygen Consumption in Response to PMA $(0.5 \mu \mathrm{g} / \mathrm{ml})$

\begin{tabular}{ccc}
\hline & Neutrophils & Monocytes \\
\hline & nmol $\mathrm{O}_{2} /$ min per $10^{6}$ cells \\
GSD 1b & $1.40 \pm 0.34^{*}$ & $1.10 \pm 0.19^{*}$ \\
& $(n=3)$ & $(n=3)$ \\
GSD 1a & $5.57 \pm 0.67$ & $2.18 \pm 0.15$ \\
& $(n=3)$ & $(n=3)$ \\
Control & $4.91 \pm 0.87$ & $2.54 \pm 0.22$ \\
& $(n=9)$ & $(n=6)$ \\
& &
\end{tabular}

Values are means \pm SD for the number of individuals in parenthesis. ${ }^{*} P<0.01$ for control vs. GSD $1 \mathrm{~b}$ and GSD la vs. GSD 1 b. Resting rates of oxygen consumption were $<0.1 \mathrm{nmol} \mathrm{O}_{2} / \mathrm{min}$ per $10^{6}$ cells in both neutrophils and monocytes and were similar in all three groups. 
Table II. Phagocyte HMPS Activity in Response to PMA

\begin{tabular}{ccc}
\hline & \multicolumn{2}{c}{ Activated/resting ratio } \\
\cline { 2 - 3 } & Neutrophils & Monocytes \\
\hline GSD 1b & $1.38 \pm 0.65^{*}$ & $2.60 \pm 1.38^{*}$ \\
& $(n=3)$ & $(n=3)$ \\
GSD 1a & $7.41 \pm 1.56$ & $5.67 \pm 1.56$ \\
& $(n=7)$ & $(n=7)$ \\
Control & $9.79 \pm 2.67$ & $6.37 \pm 1.61$ \\
& $(n=13)$ & $(n=10)$ \\
& & \\
\hline
\end{tabular}

Activated/resting ratio was determined by the rates of glucose oxidation via the HMPS in the presence of PMA (activated) and in the absence of stimuli (resting). Values are mean \pm SD for the number of individuals in parenthesis.

* $P<0.01$ for control vs. GSD $1 \mathrm{~b}$ and GSD la vs. GSD 1 b. Resting value of HMPS activity in control neutrophils and monocytes were $0.23 \pm 0.8$ and $0.26 \pm 0.7 \mathrm{nmol}{ }^{14} \mathrm{CO}_{2} / \mathrm{min}$ per $10^{6}$ cells. Resting rates in both cell types from GSD $1 \mathrm{a}$ and GSD $1 \mathrm{~b}$ patients were not significantly different from control values.

GSD $1 \mathrm{~b}$ patients produced only a 1.4-fold increase in HMPS, a minimal stimulation of the pathway as compared with controls or GSD la patients. Similarly, monocytes from GSD $1 \mathrm{~b}$ patients also showed a blunted response (a 2.6-fold increase) to PMA stimulation of HMPS activity as compared to the 6.4 and 5.7-fold increase in monocytes from control and GSD 1a patients, respectively.

Superoxide anion generation. Activation of neutrophils and monocytes by a variety of stimuli elicits the assembly of an active NADPH oxidase which generates superoxide anion. As shown in Fig. 1, after an initial lag period of $50 \mathrm{~s}$, the rate of cytochrome $c$ reduction was linear for $\sim 4 \mathrm{~min}$ in neutrophils from controls upon stimulation with PMA $(0.5 \mu \mathrm{g} / \mathrm{ml})$. In neutrophils from GSD $1 \mathrm{~b}$ patients, however, the lag period between PMA stimulation and the onset of cytochrome $c$ reduction was increased and the rate of superoxide anion generation (Fig. 1) was reduced to $30.9 \% \pm 7.7(n=3$, mean \pm SD, $P$ $<0.01$ ) of that in controls.

Superoxide anion generation in response to the chemotactic peptide f-Met-Leu-Phe was also examined in neutrophils from control, GSD la and GSD $1 \mathrm{~b}$ patients as illustrated in

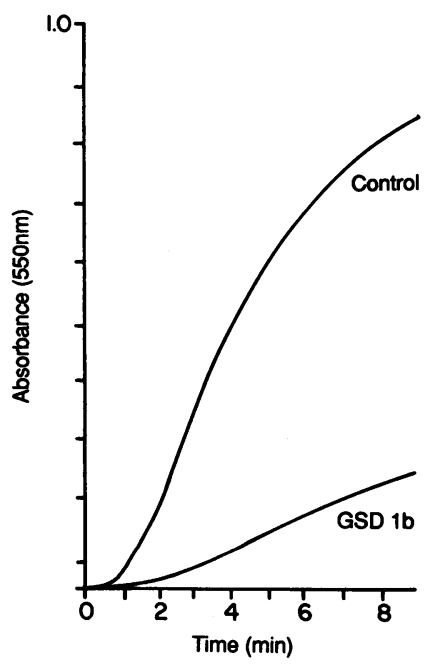

Figure 1. Superoxide anion generation in neutrophils $\times 10^{6}$ cells $/ \mathrm{ml}$ ) from control and GSD $1 \mathrm{~b}$ patients stimulated with PMA $(0.5 \mu \mathrm{g} / \mathrm{ml})$. Superoxide anion generation was monitored continuously as cytochrome $c$ reduction. Baseline cytochrome $c$ was recorded for $1 \mathrm{~min}$ before the addition of stimuli.

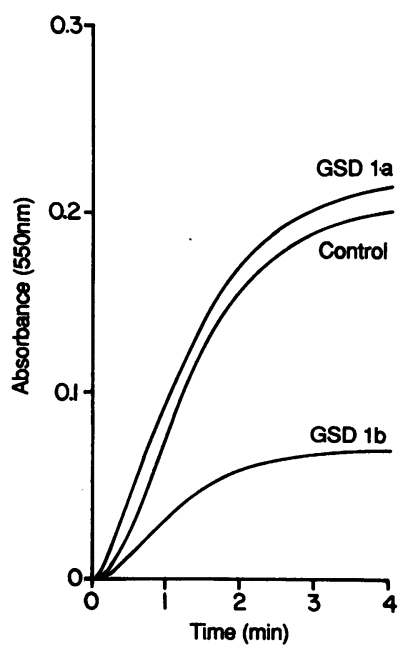

Figure 2. Superoxide anion generation in neutrophils $\left(1 \times 10^{6}\right.$ cells/ml) from control, GSD 1a, and GSD $1 \mathrm{~b}$ patients stimulated with $10^{-7} \mathrm{M}$ f-Met-Leu-Phe. Superoxide anion generation was monitored continuously as cytochrome $c$ reduction. Baseline cytochrome $\mathrm{c}$ was recorded for 1 min before the addition of stimuli.

Fig. 2. In control neutrophils, stimulated with f-Met-Leu-Phe $\left(10^{-7} \mathrm{M}\right)$, there was an initial lag period of $16 \mathrm{~s}$ which was followed by a linear rate of reduction of cytochrome $c$ for $\sim 3$ min. In neutrophils from GSD la patients, the rate of superoxide anion generation was within the range of controls. In contrast, f-Met-Leu-Phe-stimulated superoxide anion generation in neutrophils from GSD $1 \mathrm{~b}$ patients was only $16.8 \pm 13.9 \%(n=3$, mean $\pm \mathrm{SD}, P<0.01)$ of that in controls. In addition, neutrophils from GSD $1 \mathrm{~b}$ patients also demonstrated decreased superoxide anion generation as compared with controls in response to $10^{-7} \mathrm{M}$ f-Met-Leu-Phe in the absence of extracellular glucose (Fig. 3). Similarly, monocytes from GSD $1 \mathrm{~b}$ patients had an attenuated rate of superoxide anion generation when stimulated with $10^{-7} \mathrm{M}$ f-Met-Leu-Phe equal to only $31.5 \% \pm 2.4 \%(n=3$, mean $\pm \mathrm{SD}, P<0.01)$ as compared to controls.

\section{Degranulation}

F-Met-Leu-Phe is a "complete" secretagogue and triggers the extracellular release of both azurophil and specific granule

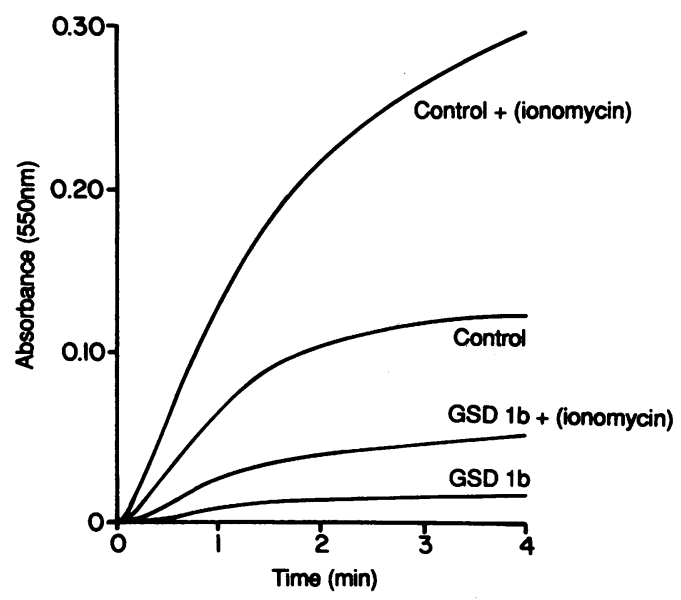

Figure 3. Effect of pretreatment with ionomycin on the time course of superoxide anion generation in neutrophils from control and GSD $\mathrm{lb}$ patients stimulated with $\mathrm{f}-\mathrm{Met}-\mathrm{Leu}-\mathrm{Phe}$. Cells were suspended in glucose-free medium and preincubated with $200 \mathrm{nM}$ ionomycin for $1 \mathrm{~min}$ at $37^{\circ} \mathrm{C}$ before the addition of $10^{-7} \mathrm{M}$ f-Met-Leu-Phe (zero time). Superoxide anion generation was measured as described in Methods and Fig. 1. 
Table III. Neutrophil Degranulation in Response to $10^{-7}$ M F-Met-Leu-Phe

\begin{tabular}{ccc}
\hline & $\beta$-glucuronidase & Lysozyme \\
\hline \multirow{3}{*}{ \% release } \\
GSD 1b & \multicolumn{3}{c}{} \\
& $29.7 \pm 3.2$ & $42.3 \pm 4.8$ \\
Control & $(n=3)$ & $(n=3)$ \\
& $29.5 \pm 2.7$ & $45.8 \pm 4.4$ \\
& $(n=6)$ & $(n=6)$
\end{tabular}

Values are means \pm SEM for the number of experiments in parenthesis.

contents as well as superoxide anion generation in cytochalasin B-treated neutrophils. As shown in Table III, there were no significant differences in neutrophils from GSD $1 \mathrm{~b}$ patients as compared to control neutrophils, in the release of either lysozyme (specific and azurophil granules) or $\beta$-glucuronidase (azurophil granules) in response to $10^{-7} \mathrm{M}$ f-Met-Leu-Phe.

\section{Calcium mobilization}

Stimulation of control neutrophils with $10^{-9} \mathrm{M}$ f-Met-LeuPhe, a concentration which stimulates chemotaxis (28), triggered a prompt increase in cytosolic calcium (Fig. 4). Resting cytosolic calcium was $70 \mathrm{nM}$; in the presence of $10^{-9} \mathrm{M}$ f-Met-Leu-Phe, cytosolic calcium rose to a peak concentration of $400 \mathrm{nM}$ by $10 \mathrm{~s}$, followed by a return toward resting levels. Restimulation of the same neutrophils with $10^{-7} \mathrm{M}$ f-MetLeu-Phe, a concentration which activates the respiratory burst, elicited a greater increase in cytosolic calcium with peak values reaching $750 \mathrm{nM}$.

In both neutrophils (Fig. 4) and monocytes (Fig. 5) obtained from GSD $1 \mathrm{~b}$ patients, resting cytosolic free calcium was similar to controls. However, both cell types showed a dramatic reduction in elevation of cytosolic free calcium in response to $10^{-9}$ and $10^{-7} \mathrm{M}$ f-Met-Leu-Phe. At the lower concentration of f-Met-Leu-Phe $\left(10^{-9} \mathrm{M}\right)$, there was little or no change in cytosolic free calcium from resting levels. The higher concentration of f-Met-Leu-Phe $\left(10^{-7} \mathrm{M}\right)$ stimulated calcium mobilization, however, the peak cytosolic free calcium was $38.4 \pm 15.2 \%(n=3$, mean $\pm \mathrm{SD}, P<0.01)$ of that in controls. This attenuated calcium response to $10^{-7} \mathrm{M}$ f-Met-

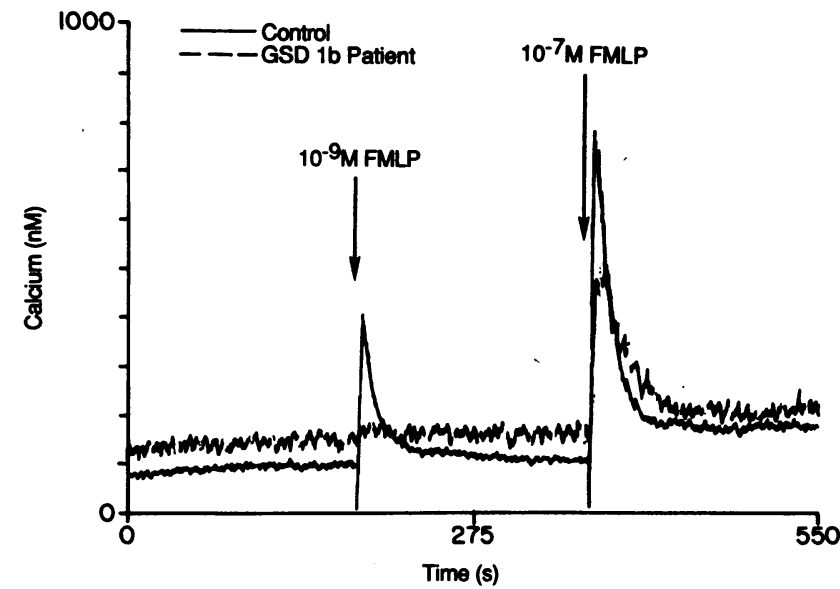

Figure 4. Time course of changes in cytosolic calcium in response to $10^{-9} \mathrm{M}$ and $10^{-7} \mathrm{M}$ f-Met-Leu-Phe in neutrophils from control and GSD $1 \mathrm{~b}$ patients. Alterations in cytosolic calcium were monitored as changes in fluorescence of fura-2-loaded cells.

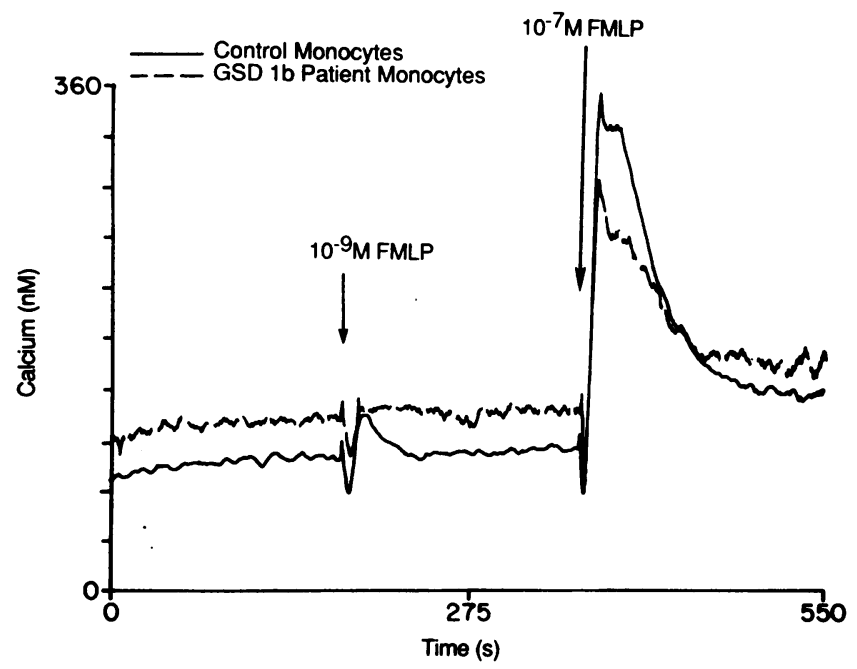

Figure 5. Time course of changes in cytosolic calcium in monocytes from control and GSD $1 \mathrm{~b}$ patients in response to stimulation with $10^{-9} \mathrm{M}$ and $10^{-7} \mathrm{M}$ f-Met-Leu-Phe.

Leu-Phe was also evident in monocytes from GSD lb patients, peak cytosolic calcium was $56.7 \pm 10.2 \%(n=3$, mean \pm SD, $P$ $<0.01$ ) of that in controls.

In contrast, neutrophils and monocytes obtained from GSD la patients showed normal mobilization of calcium and were able to attain peak levels of cytosolic calcium after stimulation with f-Met-Leu-Phe $\left(10^{-7} \mathrm{M}\right)$ that were comparable to controls. As illustrated in Fig. 6, peak cytosolic calcium levels of neutrophils from GSD la patients were $101.9 \pm 12.6 \%$ ( $n$ $=7$, mean \pm SD) as compared with controls; whereas in monocytes from GSD la patients, peak cytosolic calcium levels were $107.0 \pm 25.8 \%(n=5$, mean $\pm \mathrm{SD})$ as compared to controls.

Since monocytes as well as neutrophils isolated from GSD lb patients have an abnormal respiratory burst activity which is associated with defective calcium mobilization, we determined whether this defect was specific to phagocytic cells or whether defective calcium mobilization was a more universal finding in these patients. Lymphocytes do not undergo a respiratory burst, however in response to the lectin phytohemagglutinin (PHA), they do mobilize calcium (29). Calcium mo-

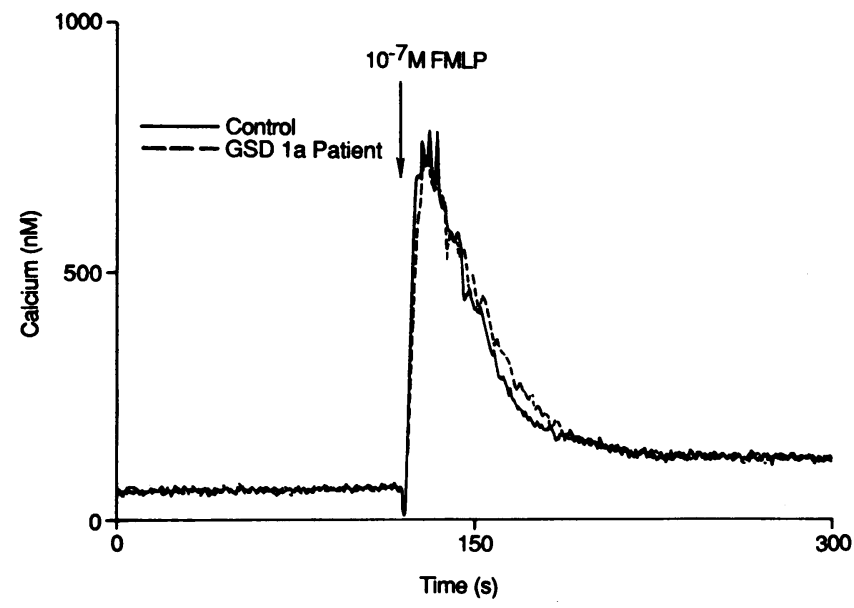

Figure 6. Time course of changes in cytosolic calcium in neutrophils from control and GSD la patients in response to stimulation with $10^{-7} \mathrm{M}$ f-Met-Leu-Phe. 
bilization in response to PHA $(100 \mu \mathrm{g} / \mathrm{ml})$ was not defective in circulating mixed lymphocytes from GSD $1 \mathrm{~b}$ patients as compared to controls (data not shown).

Effects of ionomycin on superoxide anion generation. Since calcium mobilization was found to be defective in GSD $1 \mathrm{~b}$ phagocytic cells, increasing cytosolic calcium with a calcium ionophore should correct the respiratory burst defect. Ionomycin (200 $\mathrm{nM})$ does not itself trigger significant superoxide anion generation (results not shown and reference 30). However, addition of $200 \mathrm{nM}$ ionomycin to control neutrophils, 1 min before f-Met-Leu-Phe $\left(10^{-7} \mathrm{M}\right)$ stimulation, increased the rate of superoxide anion generation by $121.3 \pm 35.0 \%(n=3$, mean $\pm S D$ ). In neutrophils from GSD $1 \mathrm{~b}$ patients, the addition of ionomycin also increased the rate of superoxide anion production by $316.3 \pm 61.2 \%(n=3$, mean $\pm \mathrm{SD}, P<0.01)$ as compared with their neutrophils stimulated with f-Met-Leu-Phe alone (Fig. 3). However, while pretreatment of neutrophils from GSD lb patients with ionomycin before f-Met-Leu-Phe stimulation did increase the rate of superoxide anion, it was still below the rate of superoxide anion generation of control cells stimulated with either ionomycin plus f-Met-Leu-Phe (14.5 $\pm 3.0 \%, n=3$, mean $\pm \mathrm{SD}, P<0.01)$ or with f-Met-LeuPhe alone (32.7 $\pm 11.2 \%, n=3$, mean \pm SD, $P<0.01$ ).

Effects of ionomycin on calcium mobilization. As shown in Fig. 7, the addition of $200 \mathrm{nM}$ ionomycin to control neutrophils results in the rapid increase in cytosolic calcium to a level of $\sim 800 \mathrm{nM}$. The addition of ionomycin to neutrophils from GSD $1 \mathrm{~b}$ patients also produced a rapid rise in cytosolic calcium, however peak calcium was $300 \mathrm{nM}$ which was signifcantly lower as compared to controls. Furthermore, measurements of cytosolic calcium triggered by ionomycin in the absence of extracellular calcium (preincubation with $5 \mathrm{mM}$ EGTA) demonstrated a smaller response in neutrophils from GSD $1 \mathrm{~b}$ patients, indicating, but not proving, that these cells may have defective intracellular calcium stores (data not shown).

\section{Discussion}

Functional defects in neutrophil activity from patients with GSD $1 \mathrm{~b}$ have been reported by a number of laboratories $(9,10$,

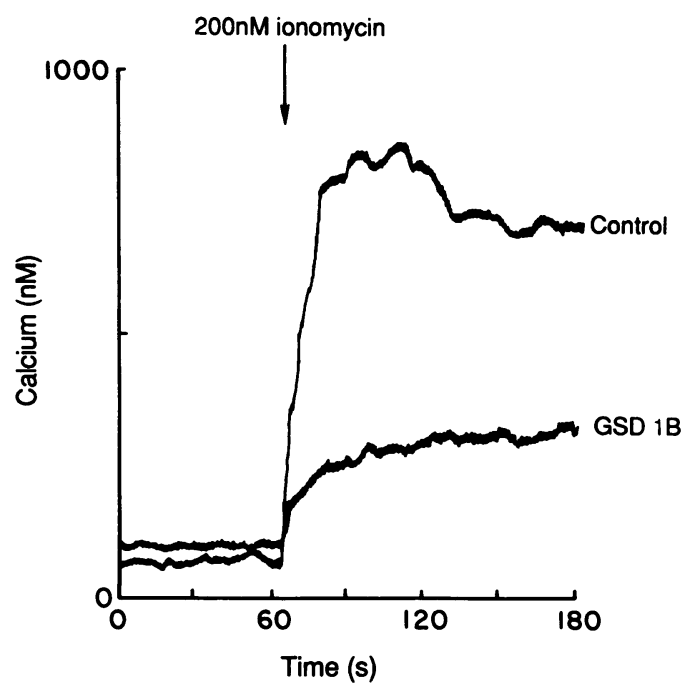

Figure 7. Time course of changes in cytosolic calcium in neutrophils from control and GSD $1 \mathrm{~b}$ patients in response to stimulation with $200 \mathrm{nM}$ ionomycin.
$12,16,31)$, though most are single case studies due to the rarity of this disease ( $<100$ reported cases). Since various stimuli have markedly different effects on different parameters associated with respiratory burst activity (32), in this study we characterized oxidative metabolism of neutrophils from GSD $1 \mathrm{~b}$ patients by three independent parameters (increased oxygen consumption, HMPS activity, and superoxide anion generation). In each of the GSD $1 \mathrm{~b}$ patients studied, neutrophil respiratory burst activity was depressed as compared to either control or GSD la patients.

Although the numbers of circulating monocytes are not decreased in patients with GSD $1 \mathrm{~b}$, these phagocytic cells have many of the same characteristics as neutrophils, including the ability to generate respiratory burst activity in response to stimulation. Ueno et al. (13) studied a single GSD $1 \mathrm{~b}$ patient's monocytes and reported normal chemotaxis but decreased chemiluminescence in response to stimuli, indicating that respiratory burst activity may also be altered in GSD 1b monocytes. The results of the present study demonstrate an impairment in respiratory burst activity in monocytes from GSD $1 b$ patients as well as in their neutrophils. However, the magnitude of inhibition in monocytes is not as severe as in their neutrophils. The reason for this difference is not apparent, but may be due to different metabolic capabilities of the two cell types; neutrophils are primarily glycolytic cells while monocytes contain more mitochondria and are capable of producing ATP via oxidative phosphorylation.

Bashan and co-workers (16) have shown decreased glucose transport in GSD $1 \mathrm{~b}$ neutrophils and postulated that this was the primary cell defect in phagocytic cells. In our studies, we have found that, when neutrophils are suspended in glucose free medium, defective respiratory burst activity remains. In the absence of glucose, neutrophils use internal glycogen stores as a carbon source (33), and it has been shown that GSD $1 \mathrm{~b}$ neutrophils have normal glycogen stores and ATP levels similar to controls (16). Therefore, it is unlikely that the blunted respiratory burst activity in neutrophils from GSD $1 \mathrm{~b}$ patients is solely a result of decreased glucose uptake.

Respiratory burst activity is dependent on both functional NADPH oxidase and HMPS pathways. There are several different sites in the pathways where a defect could occur that would alter respiratory burst activity; these include defects $(a)$ in the NADPH oxidase enzyme complex, $(b)$ in enzymes of the HMPS pathway, $(c)$ in cofactors which regulate the HMPS pathway, or $(d)$ in the activation of the oxidase.

Recently, two laboratories have demonstrated normal superoxide anion generation (10) and HMPS activity (16) in GSD $1 \mathrm{~b}$ neutrophil cell lysates. Normal activities of the enzymes glucose-6-phosphate dehydrogenase and 6-phosphogluconate dehydrogenase have also been shown in neutrophil lysates from GSD $1 \mathrm{~b}$ patients $(9,16)$. In addition, HMPS activity in resting neutrophils was normal in GSD $1 \mathrm{~b}$ (this study and reference 9). These results indicate that the enzymes in both the NADPH oxidase and the HMPS pathways are functional in these patient's neutrophils and suggest that the defect in respiratory burst activity may not be at the level of either pathway, rather it may be in the regulation of this cellular function. Decreased respiratory burst activity could then be a result of a defect in the signal transduction pathway which activates the respiratory burst.

Different ligand-receptor systems in the neutrophil can activate common physiological processes such as superoxide anion generation and degranulation (34). A defect at the level 
of the receptor could result in decreased respiratory burst activity. This does not appear to be the case in GSD $1 \mathrm{~b}$. Our results demonstrating defective respiratory burst activity triggered by three different agonists (f-Met-Leu-Phe, PMA, and latex beads) argues against a specific receptor defect in this disease. In addition, neutrophils from GSD $1 \mathrm{~b}$ patients showed normal ligand-stimulated degranulation, as measured by release of enzyme markers from either azurophil or specific granules, which supports the notion that there are intact and functional receptors on these patients' phagocytic cells.

Activation of the neutrophil by interaction of a ligand such as f-Met-Leu-Phe with its specific receptor elicits a rapid breakdown of phosphatidyl inositol 4,5-bisphosphate and generation of inositol 1,4,5 trisphosphate and diacylglycerol. This event is accompanied by a rapid elevation of cytosolic calcium and activation of protein kinase $\mathrm{C}$. Calcium is an important second messenger and is known to be involved in glycogen breakdown, glucose transport, and respiratory burst activity in phagocytic cells $(28,30,32,35)$. A dual role for calcium and protein kinase $\mathrm{C}$ has been proposed in the generation of superoxide anion generation via the activation of the membrane associated NADPH oxidase $(28,30)$. The present study demonstrates that the respiratory burst abnormality in phagocytic cells from GSD $1 \mathrm{~b}$ patients is associated with impaired calcium mobilization, whereas these processes are normal in GSD 1a patients. In GSD $1 \mathrm{~b}$ phagocytic cells, the rapid transient rise in cytosolic free calcium in response to the chemotactic peptide f-Met-Leu-Phe was markedly reduced as compared to controls. This impairment in calcium mobilization is not merely a consequence of defective respiratory burst activity, since neutrophils from patients with chronic granulomatous disease show a blunted respiratory burst but normal calcium mobilization (unpublished observation and 36). Therefore, the alteration in calcium mobilization is an indication of a signaling defect in phagocytic cells from patients with GSD 1 b.

The demonstration that superoxide anion generation is enhanced in GSD $1 \mathrm{~b}$ phagocytic cells by raising cytosolic calcium through the addition of ionomycin supports the concept that a defect in calcium mobilization is at least in part responsible for the decreased respiratory burst activity. It is thought that the transient rise in cytosolic calcium in response to $\mathrm{f}-\mathrm{Met}-\mathrm{Leu}-\mathrm{Phe}$ is a result of calcium release from the endoplasmic reticulum. The blunted rise in calcium in response to the calcium ionophore ionomycin in neutrophils from GSD $1 \mathrm{~b}$ patients, in the presence and absence of EGTA, indicates that the decreased calcium mobilization in response to f-MetLeu-Phe may be a consequence of decreased internal calcium stores. The defective ligand-induced rise in cytosolic calcium appears to be of critical significance to triggering of superoxide anion generation but not degranulation. These results are in accordance with the observation that, in control neutrophils, the buffering of intracellular calcium results in a greater diminution of superoxide anion generation than in degranulation $(30,37)$.

A role for glucose-6-phosphate in regulating calcium sequestration and release by the endoplasmic reticulum has been suggested by Wolf et al. (38) in the pancreatic islet and by Benedetti and co-workers $(39,40)$ in the liver. In light of these observations, it is possible that the absence of glucose-6-phosphate translocase activity in GSD $1 \mathrm{~b}$ may be involved in the alteration in calcium sequestration in these patients' phagocytic cells. However, this hypothesis does not explain why re- spiratory burst activity is blunted when PMA is used as a stimulus. PMA is a direct activator of protein kinase $C$ and causes the translocation of protein kinase $\mathrm{C}$ from the cell cytosol to the membrane and subsequent activation. It has been postulated that translocation of protein kinase $C$ is required for the activation of NADPH oxidase $(41,42)$. Since PMA reduces the requirement for calcium (43-46) and there is still decreased respiratory burst activity, then multiple defects must be postulated. Numerous components which regulate or are involved with phagocytic cell respiratory burst activity are membrane associated and alterations in the capabilities of any of these components would compromise bactericidal activity. The fact that the hepatic metabolic abnormality in GSD $1 \mathrm{~b}$ is associated with a membrane translocase may be indicative of a more fundamental membrane defect in this disease. However, the demonstration that calcium mobilization is normal in response to PHA in mixed lymphocyte populations from GSD $1 \mathrm{~b}$ patients indicates that defective calcium mobilization is not a global finding in circulating cells of the immune system, but is specific to phagocytic cells. Therefore, altered phagocytic cell function in GSD $1 \mathrm{~b}$ patients appears to be associated with diminished calcium mobilization and defective calcium stores. The defective calcium signaling is associated with a selective defect in respiratory burst activity but not degranulation. Further studies are required to establish the relationship between abnormal phagocytic cell function and the known hepatic defect in GSD $1 b$.

\section{Acknowledgments}

These studies were supported in part by grants NS-17752, AI-24840, and RR-00240 from the National Institutes of Health and a grant from the Heinz Foundation, and aided by Clinical Research Grant No. 6-556 from the March of Dimes Birth Defects Foundation.

\section{References}

1. Cori, G. T., and C. F. Cori. 1952. Glucose-6-phosphatase of liver in glycogen storage disease. J. Biol. Chem. 199:661-667.

2. Howell, R. R., and J. C. Williams. 1983. The glycogen storage diseases. In The Metabolic Basis of Inherited Disease. J. B. Stanbury, J. B. Wyngaarden, D. S. Frederickson, J. L. Goldstein, and M. S. Brown, editors. McGraw-Hill Book Co., New York. 141-166.

3. Senior, B., and L. Loridan. 1968. Studies of liver glycogenosis with particular reference to the metabolism of intravenously administered glycerol. N. Engl. J. Med. 279:958-965.

4. Narisawa, K., Y. Igarashi, H. Otomo, and K. Tada. 1978. A new variant of glycogen storage disease type 1 due to a defect in glucose-6phosphate transport system. Biochem. Biophys. Res. Commun. 83:1360-1364.

5. Lange, A. J., W. J. Arion, and A. L. Beaudet. 1980. Type Ib glycogen storage disease is caused by a defect in the glucose-6-phosphate translocase of the microsomal glucose-6-phosphatase system. $J$. Biol. Chem. 255:8381-8384.

6. DiRocco, M., C. Borrone, F. Dallegri, G. Frumento, and F. Patrone. 1984. Neutropenia and impaired neutrophil function in glycogenosis type 1b. J. Inherited Metab. Dis. 7:151-154.

7. Schaub, J., and K. Heyne. 1983. Glycogen storage disease type 1b. Eur. J. Pediatr. 140:283-288.

8. Beaudet, A. L., D. C. Anderson, V. V. Michels, W. J. Arion, and A. J. Lange. 1980. Neutropenia and impaired neutrophil migration in type $1 \mathrm{~b}$ glycogen storage disease. J. Pediatr. 97:906-910.

9. Narisawa, K., S. Ishizawa, H. Okumura, K. Tada, and T. Kuzuya. 1986. Neutrophil metabolic dysfunction in genetically heterogeneous patients with glycogen storage disease type $1 \mathrm{~b}$. J. Inherited. Metab. Dis. 9:297-300. 
10. Seger, R., B. Steinmann, L. Tiefenauer, T. Matsunaga, and R. Gitzelmann. 1984. Glycogenosis 1 b: neutrophil microbicidal defects due to impaired hexose monophosphate shunt. Pediatr. Res. 18:297299.

11. Bartram, C. R., H. Przyrembel, U. Wendel, H. J. Bremer, J. Schaub, and J. R. Haas. 1981. Glycogenosis type $1 \mathrm{~b}$ complicated by severe granulocytopenia resembling inherited neutropenia. Eur. J. Pediatr. 137:81-84.

12. Gahr, M., and K. Heyne. 1983. Impaired metabolic function of polymorphonuclear leukocytes in glycogen storage disease 1 b. Eur. $J$. Pediatr. 140:329-330.

13. Ueno, N., M. Tomita, T. Ariga, M. Ohkawa, S. Nagano, Y. Takahashi, S. Arashima, and S. Matsumoto. 1986. Impaired monocyte function in glycogen storage disease type 1b. Eur. J. Pediatr. 145:312314.

14. Koven, N. L., M. M. Clark, C. S. Cody, C. A. Stanley, L. Baker and S. D. Douglas. 1986. Impaired chemotaxis and neutrophil function in glycogenosis type 1b. Pediatr. Res. 20:438-442.

15. Anderson, D. C., M. L. Mace, B. R. Brinkley, R. R. Martin, and C. W. Smith. 1981. Recurrent infection in glycogenosis type lb: abnormal neutrophil motility related to impaired redistribution of adhesion sites. J. Infect. Dis. 143:447-459.

16. Bashan, N., Y. Hagai, R. Potashnik, and S. W. Moses. 1988. Impaired carbohydrate metabolism of polymorphonuclear leukocytes in glycogen storage disease $1 \mathrm{~b}$. J. Clin. Invest. 81:1317-1322.

17. Arion, W. J., A. L. Lange, H. E. Walls, and L. M. Ballas. 1980 Evidence for the participation of independent translocases for phosphate and glucose-6-phosphate in the microsomal glucose-6-phosphate system. J. Biol. Chem. 255:10396-10406.

18. Nordlie, R. C., K. A. Sukalski, J. M. Munoz, and J. J. Baldwin. 1983. Type 1c, a novel glycogenosis. J. Biol. Chem. 258:9739-9744.

19. Countaway, J. L., I. D. Waddell, A. Burchell, and W. J. Arion. 1988. The phosphohydrolase component of the hepatic microsomal glucose-6-phosphatase system is a 36.5-kilodalton polypeptide. J. Biol. Chem. 263:2673-2678.

20. Quie, P. G., J. C. White, B. Holmes, and R. A. Good. 1967. In vitro bactericidal capacity of human polymorphonuclear leukocytes: diminished activity in chronic granulomatous disease of childhood. $J$. Clin. Invest. 46:668-679.

21. Hassan, N. F., D. E. Campbell, and S. D. Douglas. 1986. Purification of human monocytes on gelatin-coated surfaces. J. Immunol. Methods 95:273-276.

22. Newburger, P. E., J. S. Pagano, J. S. Greenberger, A. Karpas, H. J. Cohen. 1980. Dissociation of opsonized particle phagocytosis and respiratory burst activity in an Epstein-Barr virus infected myeloid cell line. J. Cell Biol. 85:549-557.

23. Korchak, H. M., and G. Weissmann. 1978. Changes in membrane potential of human granulocytes antecede the metabolic responses to surface stimulation. Proc. Natl. Acad. Sci. USA. 75:38183822.

24. Brittinger, G., Hirschhorn, R., Douglas, S. D. and G. Weissmann. 1968. Studies on lysosomes. XI. Characterization of a hydrolase-rich fraction from human lymphocytes. J. Cell Biol. 37:394-411.

25. Worthington Biochemical Corp. 1972. Lysozyme assay. In Worthington Enzyme Manual, Worthington Biochemical Corp., Freehold, NJ. p. 100.

26. Korchak, H. M., L. B. Vosshall, G. Zagon, P. Ljubich, A. M. Rich, and G. Weissmann. 1988. Activation of the neutrophil by calcium mobilizing ligands. I. A chemotactic peptide and the lectin concanavalin A stimulate superoxide anion generation but elicit different calcium movements and phosphoinositide remodeling. J. Biol. Chem. 263:11090-11097.

27. Grynkiewicz, G., M. Poenie, and R. Y. Tsien. 1985. A new generation of calcium indicators with greatly improved fluorescence properties. J. Biol. Chem. 260:3440-3450.

28. Snyderman, R., and R. J. Uhing. 1988. Phagocytic cells: stimulus-response coupling mechanisms. In Inflammation: Basic Principles and Clinical Correlates. J. I. Gallin, I. M. Goldstein, and R. Snyderman, editors. Raven Press, New York. 309-323.

29. Weiss, A., J. Imboden, K. Hardy, B. Manger, C. Terhorst and J. Stobo. 1986. The role of the T3/antigen receptor complex in T-cell activation. Annu. Rev. Immunol. 4:593-619.

30. Korchak, H. M., L. B. Vosshall, K. A. Haines, C. Wilkenfeld K. F. Lundquist, and G. Weissmann. 1988. Activation of the human neutrophil by calcium mobilizing ligands. II. Correlation of calcium, diacyl glycerol and phosphatidic acid generation with superoxide anion generation. J. Biol. Chem. 263:11098-11105.

31. Heyne, K., and M. Gahr. 1980. Differentiation between glycogenosis type $1 \mathrm{a}$ and type $1 \mathrm{~b}$ by measurement of extra respiration during phagocytosis by polymorphoneuclear leukocytes. Eur. J. Pediatr. 133:69.

32. DeChatelet, L. R., C. J. Lees, C. E. Walsh, G. D. Long, and P. S. Shirley. 1982. Comparison of the calcium ionophore and phorbol myristate acetate on the initiation of the respiratory burst in human neutrophils. Infect. Immun. 38:969-974.

33. Stossel, T. P., F. Murad, R. J. Mason, and M. Vaughan. 1970 Regulation of glycogen metabolism in polymorphonuclear leukocytes. J. Biol. Chem. 245:6228-6234.

34. Weissmann, G., J. E. Smolen and H. M. Korchak. 1980. Release of inflammatory mediators from stimulated neutrophils. $N$. Engl. J. Med. 303:27-34.

35. Slonczewski, J. L., M. W. Wilde, and S. H. Zigmond. 1985 Phosphorylase a activity as an indicator of neutrophil activation by chemotactic peptide. J. Cell. Biol. 101:1191-1197.

36. Lew, P. D., C. Wollheim, R. A. Seger, and T. Pozzan. 1984 Cytosolic free calcium changes induced by chemotactic peptide in neutrophils from patients with chronic granulomatous disease. Blood. 63:231-233.

37. Lew, P. D., C. B. Wollheim, F. A. Waldvogel and T. Pozzan. 1984. Modulation of cytosolic-free calcium transients by changes in intracellular calcium-buffering capacity: correlation with exocytosis and $\mathrm{O}_{2}^{-}$production in human neutrophils. J. Cell Biol. 99:1212-1220.

38. Wolf, B. A., J. R. Colca, P. G. Comnes, J. Turk, and M. L. McDaniel. 1986. Glucose-6-phosphate regulates calcium steady state in endoplasmic reticulum of islets. J. Biol. Chem. 261:16284-16287.

39. Benedetti, A., R. Fulceri, M. Ferro, and M. Comporti. 1986. On a possible role for glucose-6-phosphatase in the regulation of liver cell cytosolic calcium concentration. Trends Biochem. Sci. 11:284-285.

40. Benedetti, A., R. Fulceri, A. Romani, and M. Comporti. 1988. MgATP-dependent glucose-6-phosphate-stimulated calcium accumulation in liver microsomal fractions. J. Biol. Chem. 263:3466-3473.

41. Horn, W., and M. L. Karnovsky. 1986. Features of the translocation of protein kinase $\mathrm{c}$ in neutrophils stimulated with the chemotactic peptide f-met-leu-phe. Biochem. Biophys. Res. Commun. 139:1169-1175.

42. Pike, M. C., L. Jakoi, L. C. McPhail, and R. Synderman. 1986. Chemoattractant-mediated stimulation of the respiratory burst in human polymorphonuclear leukocytes may require appearance of protein kinase activity in the cells' particulate fraction. Blood. 67:909913.

43. Wolf, M., P. Cuatrecasas, and N. Sayhoun. 1985. Interaction of protein kinase $C$ with membranes is regulated by calcium, phorbol esters, and ATP. J. Biol. Chem. 260:15718-15722.

44. Di Virgilio, F., D. P. Lew, and T. Pozzan. 1984. Protein kinase $\mathrm{C}$ activation of physiological processes in human neutrophils at vanishingly small cytosolic calcium levels. Nature (Lond.). 310:691-693.

45. Sha'afi, R. I., J. R. White, T. F. P. Molski, J. Shefcyk, M. Volpi, P. H. Naccache, and M. B. Feinstein. 1983. Phorbol 12 myristate 13-acetate activated rabbit neutrophils without an apparent rise in the level of intracellular free calcium. Biochem. Biophys. Res. Commun. 114:638-645.

46. Korchak, H. M., K. Vienne, L. E. Rutherford, C. Wilkenfeld, M. C. Finkelstein and G. Weissmann. 1984. Stimulus response coupling in the human neutrophil. II. Temporal analysis of changes in cytosolic calcium and calcium efflux. J. Biol. Chem. 259:4076-4082. 